\title{
Evaluation of Neoadjuvant Chemotherapy Effect in Osteosarcoma
}

\author{
Min Wook Joo, Yong-Koo Kang, le Ryung Yoo*, Woo Hee Choi*, Yang-Guk Chung, Dong-Hyun \\ Kim, and Jin-Woo Kang \\ Departments of Orthopaedic Surgery, ${ }^{\star}$ Radiology, College of Medicine, The Catholic University of Korea, Seoul, Korea
}

\begin{abstract}
Purpose: Various diagnostic imaging modalities have been used to evaluate the effect of neoadjuvant chemotherapy for osteosarcoma early and noninvasively. We evaluated the effectiveness of imaging studies of plain radiographs and positron-emission tomography/computed tomography (PET/CT) in predicting neoadjuvant chemotherapy effect for osteosarcoma and tried to establish a general principle in interpretation of PET/CT parameters.

Materials and Methods: Eighteen patients who underwent two cycles of neoadjuvant chemotherapy and surgical excision for osteosarcoma were enrolled. There were 13 males and 5 females, with a median age of 19 (11-63) years. Fifteen patients of 18 had the American Joint Committe on Cancer (AJCC) stage IIB. They had plain radiographs and PET/CT before and after neoadjuvant chemotherapy. The resected tumor specimens were pathologically examined to determine histological response grade using a conventional mapping method. Statistical analysis was performed to evaluate the correlation between histopathological necrosis rate, and radiographic finding category, post-chemotherapy maximum standardized uptake value (SUVmax), average standardized uptake value and metabolic tumor volume (MTV) as well as reduction rates of them.

Results: Eight patients were good responders to neoadjuvant chemotherapy based on histological evaluation. Median SUVmax reduction rate was 73 (23-77) \% in good responders and 42 (-32-76) \% in poor responders. Median MTV reduction rate was 93.5 (62-99) \% in good responders and $46(-81-100) \%$ in poor responders. While radiographic finding category was not different according to histological response $(p=1.0)$, SUVmax reduction rate was significantly different $(p=0.041)$. Difference in MTV reduction rates approached statistical significance as well $(\mathrm{p}=0.071)$.

Conclusion: While radiographic finding category was not reliable to assess neoadjuvant chemotherapy effect for osteosarcoma, reduction rate of SUVmax was a useful indicator in this study. As parameters of PET/CT can be influenced by various factors of settings, different centers have to make an effort to establish their own standard of judgement with reference of previous studies.
\end{abstract}

Key words: osteosarcoma, neoadjuvant therapy, necrosis, positron-emission tomography

\section{Introduction}

Osteosarcoma is the most common primary malignant bone tumor in children and young adults. ${ }^{1)}$ Although the prognosis was extremely dismal only several decades ago, the introduction of chemotherapy has dramatically improved the long-term survival rate. Today, therefore, the treatment scheme for patients with osteosarcoma is composed of neoadjuvant chemotherapy, surgery and adjuvant chemotherapy. ${ }^{2)}$ Nevertheless, chemotherapeutic agents of osteo-

Received October 31, 2014 Revised November 30, 2014

Accepted December 1, 2014

Correspondence to: Yang-Guk Chung

Department of Orthopaedic Surgery, Seoul St. Mary's Hospital, College of Medicine The Catholic University of Korea, Banpo 4-dong, Seocho-gu, Seoul 137-701, Korea

TEL: +82-2-2258-2838 FAX:+82-2-535-9834 E-mail: ygchung@catholic.ac.kr sarcoma are quite toxic ${ }^{3,4)}$ and frequently ineffective ${ }^{3,5)}$ Furthermore, continuation of ineffective neoadjuvant chemotherapy may lead to the development of resistant clones ${ }^{6}$ and delay of surgery.

Accordingly, various diagnostic imaging modalities, such as radiography, computed tomography (CT), magnetic resonance imaging (MRI) and bone scintigraphy, have been used to assess neoadjuvant chemotherapy effect early and determine whether to continue it. However, in most previous studies comparing those conventional diagnostic techniques and functional imaging such as ${ }^{18} \mathrm{~F}$-Fluoro-2deoxyglucose $\left({ }^{18} \mathrm{~F}-\mathrm{FDG}\right)$ positron-emission tomography/computed tomography (PET/CT), ${ }^{6,8-13)}$ criteria or parameters in conventional ones were less or insignificantly correlated with histological necrosis after neoadjuvant chemotherapy. Although the effectiveness of conventional radiographs in predicting histopathological response in 
Evaluation of Neoadjuvant Chemotherapy Effect in Osteosarcoma

patients with osteosarcoma treated with neoadjuvant chemotherapy was uncertain, ${ }^{14)}$ they have been still used to obtain information on tumor size, appearance, margin, cortical destruction and periosteal reaction before and after chemotherapy.

PET/CT scan can more correctly identify viable residual tumor and detect changes in tissue metabolism that generally precede the structural changes, thus it should be more accurate for assessing therapeutic response. ${ }^{15)}$ Since Jones et al. documented ${ }^{18} \mathrm{~F}$-FDG PET data of nine patients including three osteosarcoma patients who had neoadjuvant chemotherapy, ${ }^{12)}$ several studies have demonstrated that ${ }^{18} \mathrm{~F}-\mathrm{FDG}$ PET is useful for noninvasive evaluation of response to neoadjuvant chemotherapy in osteosarcoma. ${ }^{16,17)}$ A meta-analysis recently suggested cut-off values of standardized uptake and its reduction rate for predicting the histological response to chemotherapy. However, parameters of PET/CT can be influenced by various factors and it may not be easy to generalize cut-off values to predict response to chemotherapy.

We, therefore, evaluated the effectiveness of imaging studies of conventional radiographs and PET/CT in assessment of neoadjuvant chemotherapy effect for osteosarcoma and tried to establish a general principle in interpretation of PET/CT parameters.

\section{Materials and Methods}

\section{Patients and study designs}

From January 2010 to July 2013, 18 patients with histologically confirmed high-grade osteosarcoma were retrospectively enrolled. All patients had undergone an open biopsy, pre-chemotherapy plain radiographs and a pre-chemotherapy PET/CT scan before neoadjuvant chemotherapy was initiated. Patients received consistently two cycles of neoadjuvant chemotherapy, which consisted of different combinations of high-dose methotrexate, doxorubicin, ifosfamide, and dacarbazine. Each cycle of neoadjuvant chemotherapy took at least three weeks. They then had post-chemotherapy plain radiographs and a post-chemotherapy PET/CT scan before definitive surgery. The pre-chemotherapy PET/CT scans were performed within median one week (range, 0-2 weeks) before the initiation of neoadjuvant chemotherapy, and the post-chemotherapy PET/CT scans were performed within median one week (range, 0-2 weeks) after the end of chemotherapy. The resected tumor specimens were pathologically examined to estimate histological response grade using a conventional mapping method as described in previous literatures. ${ }^{18,19)}$ Our institutional review board approved this study.

\section{Categorization of ragiographic findings}

'Good' radiographic response was defined as radiographic findings such as marked decrease in tumor size, or increased ossification, definite margination and prominent periosteal new bone formation without increase in size. Other findings were categorized into 'not good' radiographic response.

\section{3. ${ }^{18} \mathrm{~F}-\mathrm{FDG}$ PET/CT}

All patients fasted for at least six hours before the ${ }^{18} \mathrm{~F}-\mathrm{FDG}$ PET/ CT study. An amount of $370-555 \mathrm{MBq}$ of ${ }^{18} \mathrm{~F}-\mathrm{FDG}$ was injected intravenously, and scanning began 60 minutes later. None of the patient had blood glucose level greater than $130 \mathrm{mg} / \mathrm{dl}$ before the injection. No intravenous contrast agent was administered. Studies were acquired on combined PET/CT in-line system, Biograph Truepoint (Siemens Medical Solutions, Knoxville, Tenn.). The acquisition time was 2-3 minutes per bed position. All patients were in supine position during PET/CT scanning. CT began at the orbitomeatal line and progressed to lower extremities $(120 \mathrm{kVp}, 50 \mathrm{mAs}$, and $5 \mathrm{~mm}$ slice thickness). PET scan followed immediately over the same body region. The CT data were used for attenuation correction, and images were reconstructed using a standard ordered-subset expectation maximization (OSEM) algorithm (two iterations, eight subsets). The axial spatial intrinsic resolution of the system was 4.5 $\mathrm{mm}$ at the center of the field of view.

\section{Measurement of Standardized Uptake Value (SUV) and Metabolic Tumor Volume (MTV) in ${ }^{18} \mathrm{~F}-\mathrm{FDG}$ $\mathrm{PET} / \mathrm{CT}$}

All ${ }^{18} \mathrm{~F}$-FDG PET/CT images were reviewed at a workstation with fusion software (Syngo; Siemens Medical Solutions, Knoxville, Tenn.) that provided multiplanar reformatted images and displayed PET images with attenuation correction, CT images, and PET/CT fusion images. The images were closely reviewed for the detection of the primary tumor by one nuclear medicine physician who are board certified in both nuclear medicine and radiology. MTV was defined as the summed volume in cubic centimeters $\left(\mathrm{cm}^{3}\right)$ including the primary tumor. The MTV was measured using a semi-automated contouring program on a Leonardo workstation (Siemens Medical Solutions, Knoxville, Tenn.), based on the tumor-to-background intensity ratio. In the measurement of targeted MTV, we set a fixed SUV cut-off value of 2.5, which was the most frequently used threshold value in previous studies measuring the MTV. ${ }^{20-22)}$ Each tumor identified was then segmented semi-automatically in three dimensions. The tumor boundaries were drawn large enough to in- 
Min Wook Joo, et al

corporate target lesions, and in transaxial, coronal and sagittal planes to reduce the confounding influence by physiologically glucoseavid. Then, an isocontour connecting the outline of the target lesion showing SUV of 2.5 was set automatically, and all voxels with SUV over 2.5 within the isocontour were included in the MTV calculation by the software. After all of the hypermetabolic lesions were segmented, the software quantified the final MTV in cubic centimeters. Maximum standardized uptake value (SUVmax) and average standardized uptake value (SUVavg) were also measured with volume of interest (VOI).

\section{Pathological assessment}

After surgery, excised specimens were cut longitudinally in the plane deemed most likely to reveal residual viable tumor, and tumor necrosis fractions were then defined as the percentage of devitalized parts of the tumor in the examined planes. Pathological good responders (GRs) and poor responders (PRs) were differentiated. $\mathrm{Ne}^{-}$ crosis fraction $\geq 90 \%$ and $<90 \%$ were considered as good response and poor response respectively.

\section{Statistical analysis}

Statistical analysis was performed to evaluate correlation between histopathological necrosis, and radiographic finding category category, post-chemotherapy SUVmax, SUVavg and MTV as well as reduction rates of them, with SPSS 21.0 for Windows (SPSS Corporation, Chicago, IL). Fisher's exact test and Mann-Whitney test were performed for radiographic finding category and post-chemothearpy SUVavg repectively. Unpaired T-tests were used for postchemotherapy SUVmax and MTV, and reduction rates of SUVmax, SUVavg and MTV. A p value $<0.05$ was considered significant.

\section{Results}

Patient age, gender, primary tumor site, American Joint Committee on Cancer (AJCC) stage, histological response grade, radiographic finding category, post-chemotherapy SUVmax, SUVavg and MTV, and reduction rates of SUVmax, SUVavg and MTV are presented in Table 1. The median age of the patients was 19 (11-63) years. Some PET/CT values were not available as seen in Table 1, because the

Table 1. Patient Characteristics, Histological Response, Radiographic Finding Category, and Values of PET/CT

\begin{tabular}{|c|c|c|c|c|c|c|c|c|c|c|c|}
\hline Age & Gender & Site & $\begin{array}{l}\text { AJCC } \\
\text { stage }\end{array}$ & $\begin{array}{c}\text { Histological } \\
\text { response } \\
\text { grade }\end{array}$ & $\begin{array}{l}\text { Radiographic } \\
\text { finding } \\
\text { category }\end{array}$ & $\begin{array}{l}\text { Post- } \\
\text { chemotherapy } \\
\text { SUVmax }\end{array}$ & $\begin{array}{l}\text { SUVmax } \\
\text { reduction } \\
\text { (\%) }\end{array}$ & $\begin{array}{l}\text { Post- } \\
\text { chemotherapy } \\
\text { SuVavg }\end{array}$ & $\begin{array}{l}\text { SUVavg } \\
\text { reduction } \\
\text { (\%) }\end{array}$ & $\begin{array}{c}\text { Post- } \\
\text { chemotherapy } \\
\text { MTV }\end{array}$ & $\begin{array}{l}\text { MTV } \\
\text { reduction } \\
(\%)\end{array}$ \\
\hline 11 & M & $\mathrm{H}$ & $\| B$ & GR & G & 4 & 74 & 2.9 & 37 & 1.9 & 96 \\
\hline 13 & $\mathrm{M}$ & $\mathrm{Fe}$ & $\| B$ & GR & $N G$ & 3 & 75 & 2.7 & 34 & 2 & 98 \\
\hline 13 & $\mathrm{~F}$ & $\mathrm{H}$ & III & GR & $N G$ & 4.3 & 56 & 2.8 & 24 & 17.7 & 91 \\
\hline 14 & M & $\mathrm{T}$ & $\| B$ & PR & $N G$ & 5.3 & NA & 3.1 & NA & 25.3 & NA \\
\hline 15 & $M$ & $\mathrm{Fe}$ & $\| B$ & GR & G & 4.1 & 74 & 3 & 47 & 1.1 & 99 \\
\hline 17 & $M$ & $\mathrm{Fe}$ & $\| B$ & PR & $N G$ & 9.1 & -32 & 3.7 & -9 & 98 & -81 \\
\hline 17 & M & $\mathrm{Fe}$ & $\| \mathrm{B}$ & GR & G & 4.9 & 64 & 3.1 & 26 & 17.6 & 73 \\
\hline 18 & $M$ & $\mathrm{Fe}$ & $\| B$ & PR & G & 5 & 37 & 3 & 12 & 15.2 & 75 \\
\hline 20 & $M$ & $\mathrm{Fe}$ & $\| B$ & PR & $N G$ & 2.5 & 76 & 2.5 & 50 & 0 & 100 \\
\hline 22 & $M$ & $\mathrm{Fe}$ & $\| B$ & PR & G & 3.9 & 11 & 2.8 & 7 & 38.9 & 27 \\
\hline 46 & M & $\mathrm{T}$ & $\| \mathrm{B}$ & PR & $N G$ & 6.4 & NA & 3.1 & NA & 5.7 & NA \\
\hline 51 & M & $\mathrm{Fe}$ & IVB & GR & G & 4 & 77 & NA & NA & NA & NA \\
\hline 63 & $\mathrm{~F}$ & Pelvis & IVA & PR & NA & 9.8 & 48 & 3.7 & 30 & 67.6 & -2 \\
\hline 39 & $F$ & $\mathrm{Fe}$ & $\| \mathrm{B}$ & GR & $N G$ & 6.6 & 23 & 3.1 & 24 & 20.3 & 62 \\
\hline 44 & $F$ & Scapula & $\| B$ & PR & G & 4.8 & 53 & 3.1 & 42 & 17.1 & 94 \\
\hline 28 & M & $\mathrm{Fe}$ & $\| \mathrm{B}$ & PR & G & 4.4 & 44 & 3.1 & 28 & 58.0 & 41 \\
\hline 12 & $\mathrm{~F}$ & $\mathrm{Fe}$ & $\| B$ & PR & $N G$ & 9.6 & 21 & 3.5 & 30 & 177.0 & 46 \\
\hline 40 & M & $\mathrm{Fe}$ & $\| B$ & PR & G & 4.3 & 42 & 2.9 & 17 & 27.8 & 62 \\
\hline
\end{tabular}

AJCC, American Joint Committee on Cancer; M, male; F, female; H, humerus; Fe, femur; T, tibia; GR, good responder; PR, poor responder; G, good; NG, not good; SUVmax, maximum standardized uptake value; SUVavg, average standardized uptake value; MTV, metabolic tumor volume; NA, not available. 
Table 2. Correlation between Histological Response and Evaluation Parameters

\begin{tabular}{|c|c|c|c|}
\hline & GR & PR & $p$-value \\
\hline $\begin{array}{l}\text { Radiographic finding category } \\
\text { G:NG }\end{array}$ & $4: 3$ & $5: 6$ & 1.0 \\
\hline $\begin{array}{l}\text { Post-chemotherapy SUVmax } \\
\text { Median (range) }\end{array}$ & $4.1(3-6.6)$ & $5(2.5-9.8)$ & 0.375 \\
\hline $\begin{array}{l}\text { SUVmax reduction (\%) } \\
\text { Median (range) }\end{array}$ & $74(23-77)$ & $42(-32-76)$ & $0.041^{*}$ \\
\hline $\begin{array}{l}\text { Post-chemotherapy SUVavg } \\
\text { Median (range) }\end{array}$ & $2.95(2.7-3.1)$ & $3.1(2.5-3.7)$ & 0.216 \\
\hline $\begin{array}{l}\text { SUVavg reduction (\%) } \\
\text { Median (range) }\end{array}$ & $30(24-47)$ & $28(-9-50)$ & 0.286 \\
\hline $\begin{array}{l}\text { Post-chemotherapy MTV }\left(\mathrm{cm}^{3}\right) \\
\text { Median (range) }\end{array}$ & $9.8(1.1-20.3)$ & $27.8(0-177.0)$ & 0.098 \\
\hline $\begin{array}{l}\text { MTV reduction (\%) } \\
\text { Median (range) }\end{array}$ & 93.5 (62-99) & $46(-81-100)$ & 0.071 \\
\hline
\end{tabular}

GR, good responder; PR, poor responder; G, good; NG, not good; SUVmax, maximum standardized uptake value; SUVavg, average standardized uptake value; MTV, metabolic tumor volume.

*Statistically significant.

PET/CT scans had been performed at referring hospitals.

Median SUVmax reduction rate was 73 (23-77) \% in GRs and 42 (-32-76) \% in PRs. Median MTV reduction rate was 93.5 (62-99) \% in GRs and 46 (-81-100) \% in PRs. Correlation between histological response and evaluation parameters are shown in Table 2. SUVmax reduction rate was significantly different according to histological response $(\mathrm{p}=0.041)$. Difference in MTV reduction rates approached statistical significance as well ( $\mathrm{p}=0.071)$. Other parameters, however, did not show the correlation with histological necrosis rate (Fig. 1).

\section{Discussion}

Conventional diagnostic imaging modalities were performed to assess neoadjuvant chemotherapy effect, such as radiography, CT, MRI, and bone scintigraphy. However, a study ${ }^{23)}$ reported that category of radiographic findings was not correlated to histological response grade at all. In addition, the reduction in tumor size assessed by conventional modalities was less correlated with histological response in previous studies. ${ }^{8,911,13)}$ Some preveious studies suggested that other findings such as changes in T2 signal on MRI and in radioisotope uptake on bone scintigraphy were not reliable, either.,10)

A meta-analysis suggested that post-chemotherapy SUVmax $\leq$ 2.5 and reduction rate of SUVmax $\geq 50 \%$ are valuable predictors to assess the chemotherapy-induced tumor necrosis. ${ }^{17)}$ SUVmax in a single pixel which represents the most aggressive portion is most widely used for determining tumor SUV, however, less sensitive to tumor shape, size, and location of the region of interest (ROI). ${ }^{24-26)}$ Although we identified that reduction rate of SUVmax was correlated with histological response grade of osteosarcoma to neoadjuvant chemotherapy in this study, the median post-chemotherapy SUVmax was 4.1 in GRs. Parameters of PET/CT can be influenced by various factors such as scanner type, timing of scanning after ${ }^{18} \mathrm{~F}-$ FDG injection, quantitative procedures, performance of attenuation correction as well as treatment details. ${ }^{17)}$ Therefore, it is not easy to generalize measurements such as cut-off values to predict response to chemotherapy. Such factors are practically different enough to report different measurements or criteria to discriminate good histological response as in previous studies from different centers. ${ }^{6,8,27)}$ Although the extremely rare incidence of only a few osteosarcoma cases per million person-years on a worldwide basis ${ }^{28)}$ makes data collection difficult, different centers have to make an effort to create their own standard of judgement and carefully accept the results of previous studies under consideration of different factors.

This current study had several limitations. It was a retrospective study and we enrolled young and old patients together in this study. The number of patients was too small, therefore, differences in evaluation parameters according to histological response to neoadjuvant chemotherapy were simply compared. In addition, we did not investigate other imaging studies such as CT, MRI and bone scintigraphy.

While radiographic finding category was not reliable to assess neoadjuvant chemotherapy effect for osteosarcoma, reduction rate of 

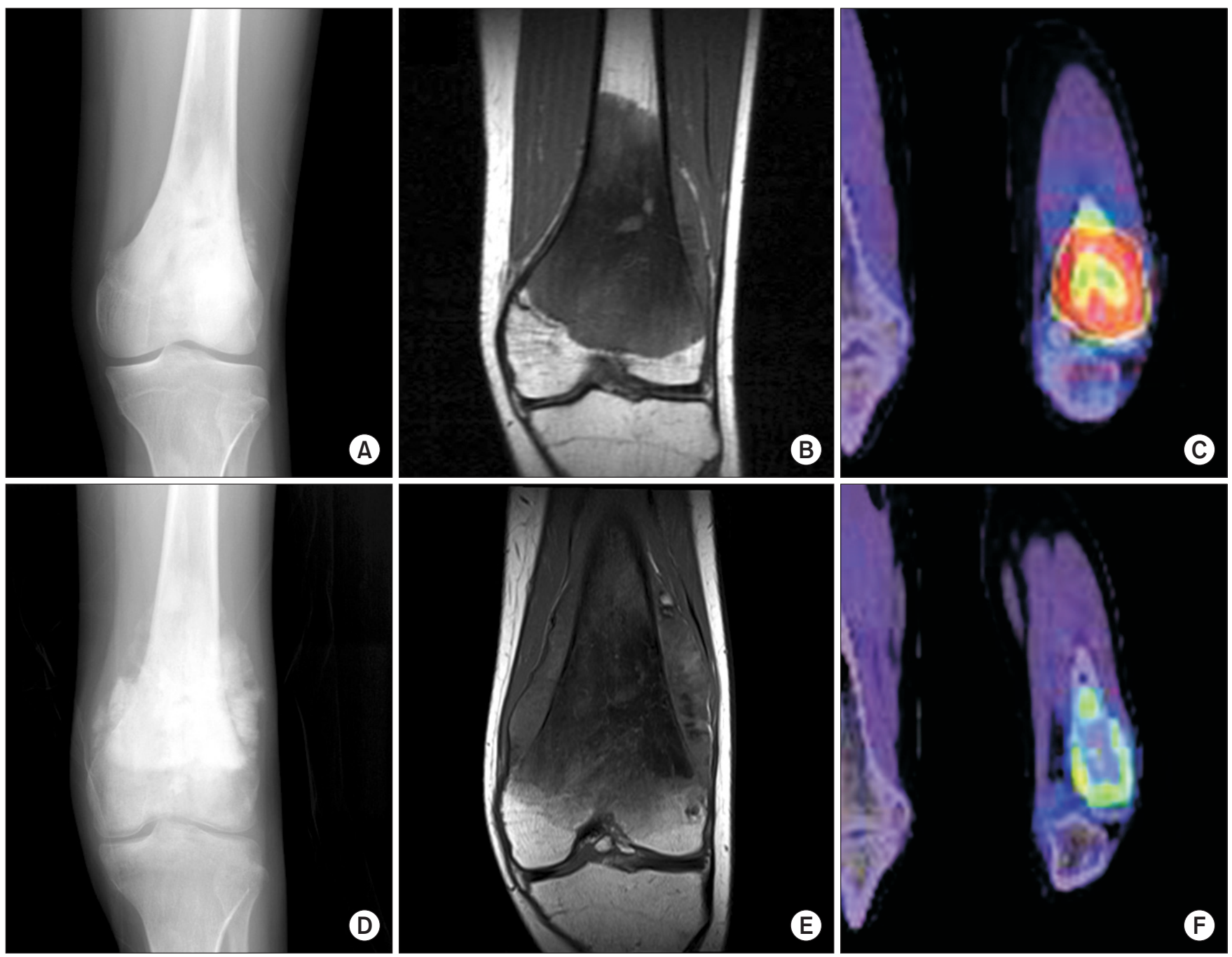

Figure 1. A 13 year-old male patient. While (D) a plain radiograph and $(E)$ an magnetic resonance imaging (MRI) after chemotherapy show marked increase in tumor size compared to (A) a plain radiograph and (B) an MRI after chemotherapy, $(\mathrm{F})$ a post-chemotherapy ${ }^{18} \mathrm{~F}$-Fluoro-2-deoxyglucose $\left({ }^{18} \mathrm{~F}-\mathrm{FDG}\right)$ positron-emission tomography/computed tomography (PET/CT) image damonstrated decrease in ${ }^{18} \mathrm{~F}-\mathrm{FDG}$ uptake compared to (C) a prechemotherapy PET/CT image. Maximum standardized uptake value decreased from 11.8 to 3.0 by $75 \%$ and the patient was identified as a good responder based on histological examination.

SUVmax was a useful indicator in this study. As parameters of PET/ CT can be influenced by various factors of settings, different centers need their own standard of judgement with reference of previous studies.

\section{Acknowledgments}

Author declares that there is no conflict of interest, grant, or financial support for this study.

\section{References}

1. Mirabello L, Troisi RJ, Savage SA. Osteosarcoma incidence and survival rates from 1973 to 2004: data from the Surveillance, Epidemiology, and End Results Program. Cancer. 2009;115:1531-43.

2. Bacci G, Longhi A, Fagioli F, Briccoli A, Versari M, Picci P. Adjuvant and neoadjuvant chemotherapy for osteosarcoma of the extremities: 27 year experience at Rizzoli Institute, Italy. Eur J Cancer. 2005;41:2836-45.

3. Bacci G, Ferrari S, Bertoni F, et al. Long-term outcome for patients with nonmetastatic osteosarcoma of the extremity treated at the istituto ortopedico rizzoli according to the istituto ortopedico rizzoli/osteosarcoma-2 protocol: an updated report. J Clin Oncol. 2000;18:4016-27.

4. Hagleitner MM, de Bont ES, Te Loo DM. Survival trends and 
long-term toxicity in pediatric patients with osteosarcoma. Sarcoma. 2012;2012:636405.

5. Kim MS, Lee SY, Lee TR, et al. Prognostic nomogram for predicting the 5-year probability of developing metastasis after neo-adjuvant chemotherapy and definitive surgery for AJCC stage II extremity osteosarcoma. Ann Oncol. 2009;20:955-60.

6. Bajpai J, Gamnagatti S, Kumar R, et al. Role of MRI in osteosarcoma for evaluation and prediction of chemotherapy response: correlation with histological necrosis. Pediatr Radiol. 2011;41:441-50.

7. Jeon DG, Song WS. How can survival be improved in localized osteosarcoma? Expert Rev Anticancer Ther. 2010;10:1313-25.

8. Benz MR, Czernin J, Tap WD, et al. FDG-PET/CT Imaging Predicts Histopathologic Treatment Responses after Neoadjuvant Therapy in Adult Primary Bone Sarcomas. Sarcoma. 2010;2010:143540.

9. Denecke T, Hundsdörfer P, Misch D, et al. Assessment of histological response of paediatric bone sarcomas using FDG PET in comparison to morphological volume measurement and standardized MRI parameters. Eur J Nucl Med Mol Imaging. 2010;37:1842-53.

10. Franzius C, Sciuk J, Brinkschmidt C, Jürgens H, Schober O. Evaluation of chemotherapy response in primary bone tumors with F-18 FDG positron emission tomography compared with histologically assessed tumor necrosis. Clin Nucl Med. 2000; 25:874-81.

11. Hamada K, Tomita Y, Inoue A, et al. Evaluation of chemotherapy response in osteosarcoma with FDG-PET. Ann Nucl Med. 2009;23:89-95.

12. Jones DN, McCowage GB, Sostman HD, et al. Monitoring of neoadjuvant therapy response of soft-tissue and musculoskeletal sarcoma using fluorine-18-FDG PET. J Nucl Med. 1996;37:1438-44.

13. Tateishi U, Kawai A, Chuman H, et al. PET/CT allows stratification of responders to neoadjuvant chemotherapy for high-grade sarcoma: a prospective study. Clin Nucl Med. 2011;36:526-32.

14. Holscher HC, Hermans J, Nooy MA, Taminiau AH, Hogendoorn PC, Bloem JL. Can conventional radiographs be used to monitor the effect of neoadjuvant chemotherapy in patients with osteogenic sarcoma? Skeletal Radiol. 1996;25:19-24.

15. Cheon GJ, Kim MS, Lee JA, et al. Prediction model of chemotherapy response in osteosarcoma by $18 \mathrm{~F}-\mathrm{FDG}$ PET and MRI. J Nucl Med. 2009;50:1435-40.
16. Caldarella C, Salsano M, Isgrò MA, Treglia G. The Role of Fluorine-18-fluorodeoxyglucose Positron Emission Tomography in Assessing the Response to Neoadjuvant Treatment in Patients with Osteosarcoma. Int J Mol Imaging. 2012;2012: 870301.

17. Hongtao L, Hui Z, Bingshun W, et al. 18F-FDG positron emission tomography for the assessment of histological response to neoadjuvant chemotherapy in osteosarcomas: a meta-analysis. Surg Oncol. 2012;21:e165-70.

18. Picci P, Bacci G, Campanacci M, et al. Histologic evaluation of necrosis in osteosarcoma induced by chemotherapy. Regional mapping of viable and nonviable tumor. Cancer. 1985;56:151521.

19. Picci P, Sangiorgi L, Rougraff BT, Neff JR, Casadei R, Campanacci M. Relationship of chemotherapy-induced necrosis and surgical margins to local recurrence in osteosarcoma. J Clin Oncol. 1994;12:2699-705.

20. Greco C, Rosenzweig K, Cascini GL, Tamburrini O. Current status of PET/CT for tumour volume definition in radiotherapy treatment planning for non-small cell lung cancer (NSCLC). Lung Cancer. 2007;57:125-34.

21. Konski A, Doss M, Milestone B, et al. The integration of 18-fluoro-deoxy-glucose positron emission tomography and endoscopic ultrasound in the treatment-planning process for esophageal carcinoma. Int J Radiat Oncol Biol Phys. 2005;61:1123-8.

22. Nestle U, Kremp S, Schaefer-Schuler A, et al. Comparison of different methods for delineation of 18F-FDG PET-positive tissue for target volume definition in radiotherapy of patients with non-Small cell lung cancer. J Nucl Med. 2005;46:1342-8.

23. Smith J, Heelan RT, Huvos AG, et al. Radiographic changes in primary osteogenic sarcoma following intensive chemotherapy. Radiological-pathological correlation in 63 patients. Radiology. 1982;143:355-60.

24. Vanderhoek M, Perlman SB, Jeraj R. Impact of the definition of peak standardized uptake value on quantification of treatment response. J Nucl Med. 2012;53:4-11.

25. Velasquez LM, Boellaard R, Kollia G, et al. Repeatability of $18 \mathrm{~F}-\mathrm{FDG}$ PET in a multicenter phase I study of patients with advanced gastrointestinal malignancies. J Nucl Med. 2009;50:1646-54.

26. Wahl RL, Jacene H, Kasamon Y, Lodge MA. From RECIST to PERCIST: Evolving Considerations for PET response criteria in solid tumors. J Nucl Med. 2009;50 Suppl 1:122S-50S. 
Min Wook Joo, et al

27. Im HJ, Kim TS, Park SY, et al. Prediction of tumour necrosis fractions using metabolic and volumetric 18F-FDG PET/CT indices, after one course and at the completion of neoadjuvant chemotherapy, in children and young adults with osteosarcoma. Eur J Nucl Med Mol Imaging. 2012;39:39-49.
28. Bielack SS, Kempf-Bielack B, Delling G, et al. Prognostic factors in high-grade osteosarcoma of the extremities or trunk: an analysis of 1,702 patients treated on neoadjuvant cooperative osteosarcoma study group protocols. J Clin Oncol. 2002;20:776-90. 


\section{골육종에서 술전 항암화학요법의 효과 판정 주민욱 • 강용구 • 유이령* • 최우희 ${ }^{\star}$ 정양국 - 김동현 • 강진우 가톨릭대학교 의과대학 정형외과학교실, 방사선과학교실}

목적: 골육종에 대한 술전 항암화학요법의 효과를 조기에 비침습적으로 평가하기 위해 다양한 영상 진단 기법들을 사용해 왔다. 저자 들은 골육종에 대한 술전 항암화학요법의 효과를 예측하는 데 있어 단순 촬영 및 양전자 방출 단층 촬영과 같은 영상 검사들의 효용성 을 평가하고 양성자 방출 단층 촬영에서 얻어진 값들을 해석하는 데 있어서의 통칙을 정해 보고자 하였다.

대상 및 방법: 2 주기 술전 항암화학요법 후 외과적 절제를 시행한 18 명의 골육종 환자들을 대상으로 하였다. 남자 13 명, 여자 5 명이었 으며, 연령의 중위수는 19 세였다. 술전 항암화학요법의 전후로 단순 촬영 및 양전자 방출 단층 촬영을 시행하였다. 절제된 종양에 대 해 병리검사를 시행하여 조직학적 반응 등급을 확인하였다. 조직병리학적 괴사 정도와 방사선학적 소견, 술전 항암화학요법 후 최대 표 준섭취계수(maximum standardized uptake value), 평균 표준섭취계수(average standardized uptake value), 대사종양용적(metabolic tumor volume) 및 해당 값들의 감소율에 대해 통계학적 분석을 시행하였다.

결과: 조직학적 평가 상, 8 명의 환자에서 술전 항암화학요법에 대해 좋은 반응을 확인하였다. 최대 표준섭취계수 감소율의 중위수 는 좋은 반응을 보인 군에서 74 (23-77) \%였고, 나머지에서 42 (-32-76) \%였다. 대사종양용적 감소율의 중위수는 좋은 반응을 보 인 군에서 93.5 (62-99) \%였고 나머지에서 46 (-81-100) \%였다. 방사선학적 소견의 범주는 조직학적 반응에 따른 차이가 없었지만 $(\mathrm{p}=1.0)$, 최대 표준섭취계수의 감소율은 유의한 차이를 보였다 $(\mathrm{p}=0.041)$. 대사종양용적의 감소율 차이는 통계학적 유의성에 근접하였 다 $(\mathrm{p}=0.071)$.

결론: 본 연구에서 방사선학적 소견의 범주는 골육종에 대한 술전 항암화학요법의 효과를 평가하는 데 있어 신뢰할 수 없었지만, 최대 표준섭취계수는 유용한 척도였다. 양전자 방출 단층 촬영에서 얻어지는 값들은 여러 요인에 의해 영향을 받으므로, 각 기관은 기왕의 연구들을 참고로 각자의 판단 기준을 마련하기 위해 노력해야만 한다.

색인단어: 골육종, 술전 항암화학요법, 괴사, 양전자방출단층촬영

접수일 2014년 10월31일 심사수정일 2014년 11월30일 게재확정일 2014년 12월1일 교신저자정양국

서울시서초구 반포 4동, 가톨릭대학교 의과대학 서울성모병원 정형외과

TEL 02-2258-2838, FAX 02-535-9834, E-mail ygchung@catholic.ac.kr 